\title{
Hepatic Stellate Cell: A Double-Edged Sword in the Liver
}

\author{
Nianan LUO ${ }^{1,2}$, Jiangbin LI $^{1}$, Yu WEI ${ }^{3}$, Jianguo LU ${ }^{1}$, Rui DONG \\ ${ }^{1}$ Tangdu Hospital, Fourth Military Medical University, Xi'an, Shaanxi, China, ${ }^{2} 943$ Hospital of \\ PLA, Wuwei, Gansu, China, ${ }^{3} \mathrm{HuBei}$ Sheng EnShiZhou Central Hospital, Enshi, HuBei, China
}

Received July 3, 2021

Accepted August 26, 2021

Epub Ahead of Print October 30, 2021

\begin{abstract}
Summary
Hepatic stellate cells (HSCs) are located in the space of Disse, between liver sinusoidal endothelia cells (LSECS) and hepatocytes. They have surprised and excited hepatologists for their biological characteristics. Under physiological quiescent conditions, HSCs are the major vitamin A-storing cells of the liver, playing crucial roles in the liver development, regeneration, and tissue homeostasis. Upon injury-induced activation, HSCs convert to a pro-fibrotic state, producing the excessive extracellular matrix (ECM) and promoting angiogenesis in the liver fibrogenesis. Activated HSCs significantly contribute to liver fibrosis progression and inactivated HSCs are key to liver fibrosis regression. In this review, we summarize the comprehensive understanding of HSCs features, including their roles in normal liver and liver fibrosis in hopes of advancing the development of emerging diagnosis and treatment for hepatic fibrosis.
\end{abstract}

\section{Key words}

HSCs • Quiescent HSCs • Activated HSCs • Liver fibrosis • Normal liver

\section{Corresponding author}

R. Dong, Tangdu Hospital, Fourth Military Medical University, Xi'an, Shaanxi, 710038, China, E-mail: dongrui2020@yeah.net, and JG. LU, Tangdu Hospital, Fourth Military Medical University, Xi'an, Shaanxi, 710038, China, E-mail: lujguo@yeah.net

\section{Introduction}

As a metabolic organ, the liver is known for its regenerative capacity, and plays an important role in the body such as synthesizing, breaking down, filtering, storing and producing bile (Grunsven 2017). The liver consists of parenchymal cells (hepatocytes) and non-parenchymal cells (NPCs) such as HSCs, LSECs, biliary epithelial cells, Kupffer cells, natural killer cells, B cells and macrophages (Mazza et al. 2017). Hepatic fibrosis is a dynamic process and results from chronic liver injury of different etiologies, containing chronic viral infection (e.g. HBC, HCV), alcoholic liver disease (ALD), fatty liver disease, non-alcoholic fatty liver disease (NAFLD)/nonalcoholic steatohepatitis (NASH) and other conditions (Sherman 2018). Hepatic fibrosis is considered as a reversible pathological process, characterized by excessive accumulation of ECM (Schildberg et al. 2015). HSCs play a vital role in the fibrogenesis, differentiating into myofibroblasts leading to hepatic fibrosis after activated (Friedman 2008b).

HSCs located in the perisinusoidal space of Disse are the main ECM-producers of the liver, and significantly contribute to its roles by interaction with adjacent cells (Lee et al. 2015). In a healthy liver, quiescent HSCs represent $15 \%$ of the total number of liver cells and preserve retinoid storage (Seki 2015). Upon liver injury, HSCs receive signals and become activated, transdifferentiating into ECM-producing myofibroblast-like cells, activated HSCs are proliferative and fibrogenic phenotype (Fig. 1). This review focuses on the understanding of HSCs to grasp the characteristics of quiescent HSCs and activated HSCs, directing therapeutic targeting of anti-fibrotic strategy.

\section{Embryonic origin and ultrastructure of HSCs}

In 1876, the HSC was found by Kupffer using gold chloride method (Doherty 2016). As a vitamin 


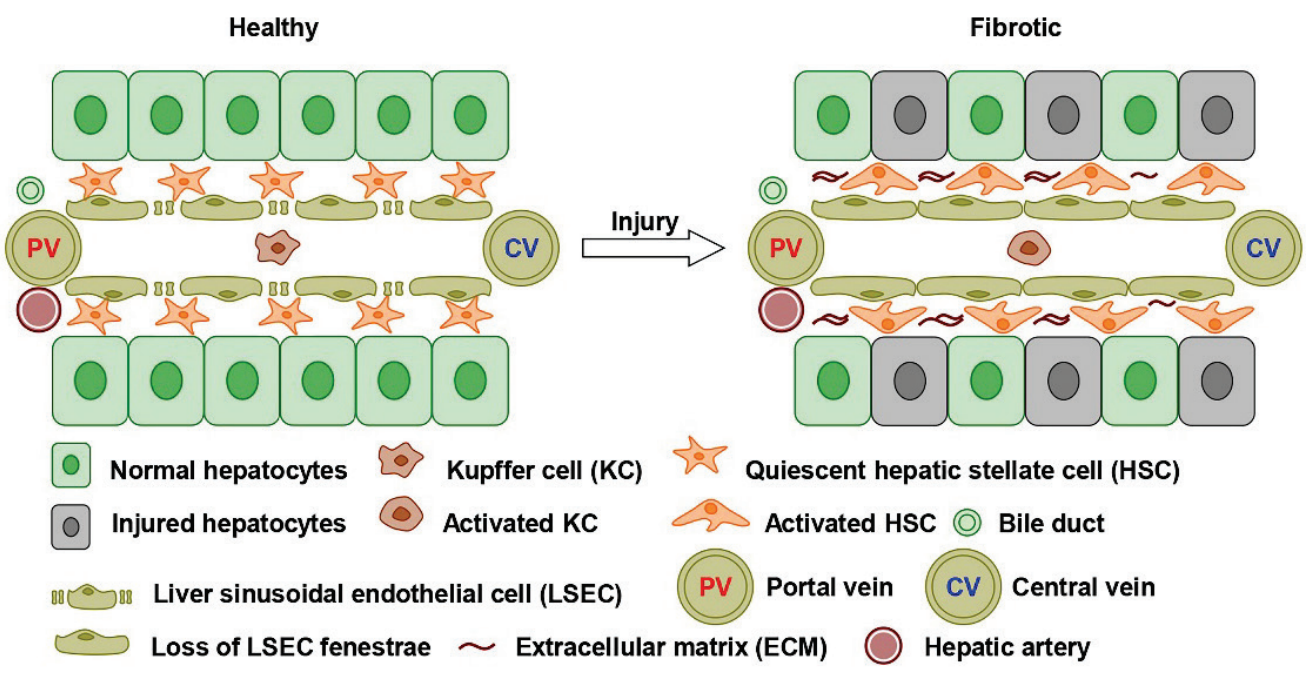

Fig. 1. Anatomical position of HSCs and liver sinusoids to injury. HSCs are located in the space of Disse, between LSECs and hepatocytes. Under liver injury, HSCs convert to a pro-fibrotic state, producing the excessive ECM and promoting the liver fibrogenesis.

A-storing mesenchymal cell type, HSC is crucial to liver regeneration and fibrosis (Koyama et al. 2017). The embryonic origin of HSCs is unclear because they express marker genes of the endoderm and mesodermal (Friedman 2008a, Marrone et al. 2016). In the view of an endoderm origin, HSCs express CD34 and cytokeratin-7/8, which are typically localized to the endodermal during liver development (Eggert et al. 2017). In the view of a mesodermal origin, lineage tracing of the mesoderm transcriptional factor Foxfl showed that HSCs develop from the septum transversum mesenchyme, suggestive of a mesodermal origin (Yanguas et al. 2016). Meanwhile, bone marrow- and neural-derived cells are also thought to contribute to both quiescent and activated HSCs (Zoubek et al. 2017).

HSC is one of the non-parenchymal cells in the liver, also known as fat-storing cell, Ito cells, lipocyte, interstitial cell, perisinusoidal cell or vitamin A-storing cell (Schumacher et al. 2016). HSCs are located in the space of Disse, communicating with the neighboring cell types such as hepatocytes, LSECs, biliary epithelial cells, hepatic progenitor cells, Kupffer cells and B cells via soluble mediators or cytokines (Thompson et al. 2015). HSCs in normal liver have irregular star-shaped cell bodies with round or oval nuclei (Koyama et al. 2016). In quiescent state, they do not or rarely express $\alpha$-smooth muscle actin ( $\alpha$-SMA), with low proliferative activity and low capacity of collagen synthesis (Huang et al. 2017). Their perikaryons lie in recesses between hepatocytes and LSECs (Bansal 2016). They have small Golgi complex, rough endoplasmic reticulum (rER) and dendritic cytoplasmic protuberances (Kitano et al. 2016).

\section{Activation and deactivation of HSCs}

HSCs are quiescent in normal liver, the functions of quiescent HSCs mainly include vitamin A-metabolizing and -storing, fat-storing, synthesis of matrix metallo proteinase (MMP) and tissue inhibitor of metallo proteinase (TIMP-1), expression of cytokines and receptors, and regulation of liver sinusoidal blood (Tsuchida et al. 2017). HSCs are activated when the liver is damaged by inflammation or mechanical stimulation, its features contain expression of $\alpha$-SMA, secretion of ECM and so on (Shang et al. 2018). The mechanism of HSCs activation is complex, including cellular events, molecular dysregulation, and other complex factors (Seki 2015). As the predecessors of proliferative myofibroblasts, activated HSCs spark efforts to understand their phenotypes transdifferentiation and how they contribute to liver fibrosis (Jung et al. 2017). Quiescent HSC is identified in a nonproliferative state, with a distinctive feature of cytoplasmic lipid droplets (Hellerbrand 2013). Upon liver injury, HSCs become activated, transdifferentiating to myofibroblasts (Preziosi et al. 2017). These activated HSCs are proliferative, contractile, and characterized by excessive ECM production (Zhang et al. 2016). Other resident liver cells promote or inhibit HSCs activation via released or secreted factors (Fig. 2). The sequence of HSC activation featuring initiation followed by perpetuation (Hsieh et al. 2015). Initiation is characterized by events rendering the HSCs responsive to many extracellular signals (Seo et al. 2016). Development of a contractile and fibrogenic phenotype, modulation of growth factor signaling, as well as are initiation phase features (Zhou et al. 2014). Perpetuation characterizes amplification of 

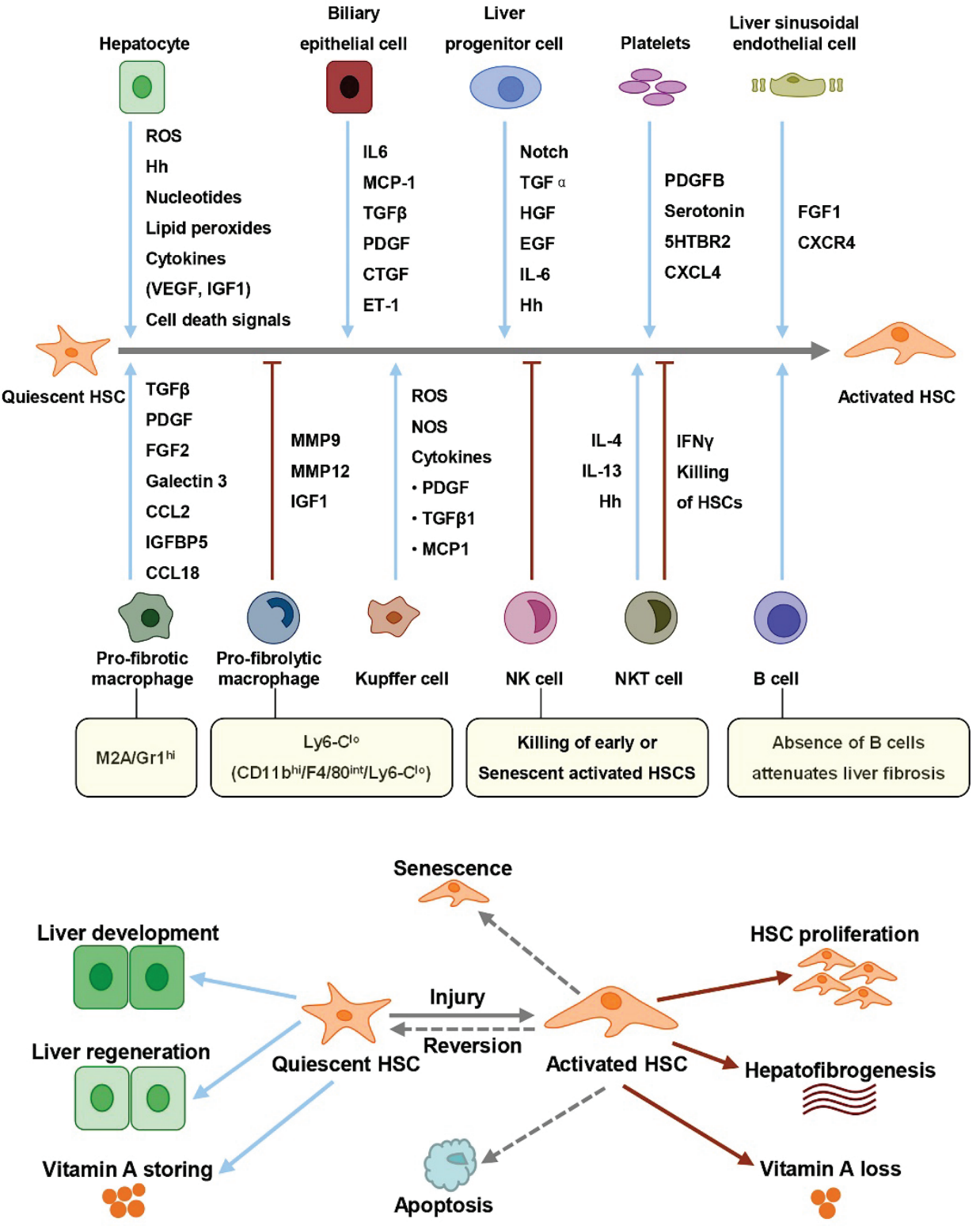

Fig. 2. Liver resident cells modulators of HSCs activation. HSCs activation is promoted or suppressed by multiple cell types. Liver resident cells promote (green lines) or suppress (red lines) quiescent HSCs to activated HSCs. ROS, reactive oxygen species; $\mathrm{Hh}$ hedgehog; VEGF, vascular endothelial growth factor; IGF1, insulin-like growth factor 1; IL6, inter leukin 6; MCP-1, monocyte chemoattractant protein-1; TGF $\beta$, transforming growth factor $\beta$; PDGF, plateletderived growth factor; CTGF, connective tissue growth factor; ET-1, endothelin-1; HGF, hepato-cyte growth factor; EGF, epidermal growth factor; FGF1, fibroblast growth factor 1; IFNy, interferon-Y; NOS, nitric oxide synthase; IGFBP5, insulin-like growth factor binding protein 5 ; NKT, natural killer T; NK, natural killer.

Fig. 3. Functions, features and phenotypes of HSC in normal and liver fibrosis, and activated HSC clearance approaches. Quiescent HSC in normal liver plays a vital role during liver development, regeneration, and vitamin A storage. Activated HSC is related with liver fibrosis. There are three activated HSCs clearance approaches: apoptosis, senescence, and reversion. the activated phenotype (Elpek 2014). The perpetuation phase results in fibrogenesis through matrix production, contractility, proinflammatory signaling and enhanced HSC proliferation (Tsuchida et al. 2017).

There are three ways of activated HSCs elimination: reversion, senescence and apoptosis (Friedman 2008b). The reversion of activated HSCs to inactivated state has shown a vital role in hepatic fibrosis regression, suggesting the expression of fibrogenic genes relative to activated HSCs was reduced. HSC senescence also plays a crucial role in liver fibrosis recovery, senescent HSCs represented reduced ECM component production (DeRossi et al. 2019). In the liver, HSC apoptosis has been reported during hepatic fibrosis reversion through two approaches: mitochondrial dependence and death receptors (Tao et al. 2019). The mechanisms of HSCs activation and deactivation could provide antifibrotic targeted therapeutic strategies (Wang et al. 2020).

\section{HSCs in normal liver}

A fundamental understanding of the feature and function of HSCs in normal liver is essential to explore their role in liver diseases. Researches of HSCs in normal liver have showed that they play a vital role during liver development, regeneration, vitamin A storage and other processes (Fig. 3).

\section{HSCs in liver development}

Throughout the liver development, HSCs are closely related to hematopoietic cells, liver progenitor 
cells, biliary epithelial cells, LSECs, hepatocytes and Kupffer cells (Lee et al. 2015). It suggests that HSCs may contribute to hepatic organogenesis via regulating the growth, differentiation, or morphogenesis of these cells (Arab et al. 2020). As is well-known, the liver is the primary site of hematopoiesis during mammalian embryogenesis. HSCs are involved in fetal liver hematopoiesis through the secretions of $\mathrm{Hlx}$ and CXCL12 (Friedman 2008a, Yin et al. 2013). HSCs also can promote the progenitor cells maturation through its markers ( $\alpha$-SMA, desmin and vimentin) (Arriola et al. 2019). Quiescent HSCs express mesenchymal morphogenic proteins pleiotrophin and epimorphin, which are contribute to liver regeneration after partial hepatectomy (Chen et al. 2020).

HSCs may also be critical to the morphogenesis of intrahepatic bile ducts via interacting with biliary epithelial cells (Chen et al. 2020). Fetal HSCs secrete hepatocyte growth factor (HGF), this growth factor has significant effects on the development of biliary epithelial cells during hepatic organogenesis (Das et al. 2020). In the injured liver, HSCs expressed hepatocyte and epithelial cell markers. The role of these cells in biliary epithelial cells differentiation is not quite clear, which may be mediated by cell-cell contacts (Dong et al. 2020). In both fetal and adult livers, HSCs and LSECs have been proposed to share a common precursor because of their location proximity and coexpression of angiogenic factors, their communication by means of paracrine signaling (Hoffmann et al. 2020). During angiogenesis, HSCs are thought to have the same effect on the vascular tube maturation and integrity with LSECs when the liver responds to injury, understanding their interactions during growth is vital for liver injury recovery (Kong et al. 2020).

\section{HSCs in liver regeneration}

A deep understanding of the relationship between HSCs and liver regeneration has important significances for stimulating liver recovery following partial hepatectomy (PH) (Forbes et al. 2016). Activated HSCs have involved in liver regeneration through producing hepatocyte proliferation factors, angiogenic factors and remodeled ECM, these cytokines and chemokines directly promote the proliferation of hepatocytes, and act indirectly through LSECs or Kupffer cells to stimulate regeneration ( $\mathrm{Li}$ et al. 2020). Activated HSCs-derived HGF can promote hepatocytes proliferation during liver injury. However, HSCs also can inhibit the hepatocyte proliferation, HSCs-derived transforming growth factor- $\beta$ (TGF- $\beta$ ) is the antiproliferative factor, and even induces apoptosis (Yin et al. 2013). Therefore, liver regeneration is a complex process, HSCs modulate the process both the initiation and termination.

Quiescent HSCs are critical to the liver regenerative response in injured liver, they contribute to hepatocellular development following injury, reducing hepatic fibrosis and diminishing the expression of $\alpha$-SMA (Friedman 2008a). At the same time, activated HSCs can increase liver cell injury and even apoptosis. The role of HSCs in liver injury and repair is unclear because they have quiescence and activation phenotypes ( $\mathrm{Li}$ et al. 2020). An advanced model in vivo and in vitro is necessary to clarify the function of these enigmatic cells.

\section{Vitamin A storage and metabolism}

In normal liver, HSCs present a quiescent state, which are characterized by vitamin $\mathrm{A}$ in their cytoplasmic droplets in the form of retinyl esters. There are two types of vitamin A droplets: type I and type II (Friedman 2008a). Under physiological conditions, the vast majority of vitamin A in the liver is stored in HSCs, showing a heterogeneous pattern. Under liver injury, HSCs become activated and lose these characteristic droplets (Lv et al. 2020). The form of vitamin released outside the activated HSCs is retinol, indicating that there is intracellular hydrolysis of esters, rather than export. Several nuclear retinoid receptors secreted by HSCs mediate vitamin A metabolism in the liver, such as retinol-binding protein (RBP), lecithin retinol acetyl transferase (LRAT) and peroxisome proliferator-activated receptors (PPARs). The roles of vitamin A storage and metabolism in the HSCs of liver merit further investigation (Miyazoe et al. 2020).

\section{HSCs in liver fibrosis}

The facilitation of liver development and regeneration may be feasible in normal liver, HSCs can also be related with liver diseases, especially liver fibrosis. The overwhelming majority of hepatic fibrosis result in the hepatic carcinoma, the relationship between HSCs and liver fibrosis has been recognized (Nagasaki et al. 2020). Studies suggest that activated HSCs can be involved in hepatic fibrogenesis due to the production of extracellular matrix accumulation. Phenotypic transformation from quiescent HSCs to activated HSCs contributes to many forms of liver fibrosis, at least there are three activated HSCs clearance approaches: apoptosis, 
senescence, and reversion (Tao et al. 2020). Each clearance way of activated HSCs contributes to a decrease in the number of this ECM-producing cell type, resulting in the regression of hepatic fibrosis. Targeting HSCs provide anti-fibrotic strategies for liver fibrosis therapies. Therefore, the comprehensive understanding of HSCs is necessary to promote the resolution of liver fibrosis (Wang et al. 2020).

\section{ECM-producing cell}

Liver fibrosis is caused by chronic liver injury and considered as ECM excess. The unbalance between synthesis and degradation of ECM results in hepatic fibrogenesis, HSCs are the central regulators of liver fibrosis (Wang et al. 2020). In normal liver, HSCs have key roles in vitamin A storage and metabolism. Under liver injury, quiescent HSCs are activated via the mediation of ROS, MCP-1, HGF, CXCR4, CCL2, and activated HSCs are the major ECM producer (Yang et al. 2020). The activated phenotype is characterized as proliferation, contractility, fibrogenesis and retinoid loss, promoting the accumulation of ECM by increasing the expression of collagen type $\mathrm{I}$ and decreasing the expression of MMP (Zhang et al. 2020).

\section{Angiogenesis in liver fibrogenesis}

Angiogenesis has a key role in liver fibrogenesis and progression. HSCs also mediate angiogenesis through the stimulation of vascular endothelial growth factor (VEGF), which is pro-angiogenic factor. The overexpression of VEGF is associated with liver fibrosis grade and portal hypertension, indicating the important role of pro-angiogenic factor VEGF in liver fibrogenesis (Zou et al. 2019). Activated HSCs are considered to secrete pro-angiogenic factors such as VEGF, IGF1, TGF- $\beta$ and EGF, and express angiogenic growth factor receptors (Chen et al. 2020, Moon et al. 2019). In liver fibrosis, these factors contribute to pro-angiogenic microenvironment, and their upregulation induces liver fibrogenesis.

\section{Conclusion}

As summarized in this review, the HSCs play a critical role in liver development, liver regeneration and hepatic fibrogenesis. Vital regulators of liver fibrosis have been characterized, and HSCs have been identified as potential therapeutic targets for hepatic fibrosis (Dong et al. 2020, Zhang et al. 2019). Concerted efforts to explore the mechanisms that HSCs activation and clearance will enhance the efficiency of targeting these cells in liver fibrosis. The application of targeting HSCs in clinical trials requires further investigation, the function of HSCs and their regulation mechanisms in other tissue are unclear (Zhai et al. 2019). Furthermore, advanced models are necessary for in vivo and in vitro studies of HSCs in the liver, to probe the regulation of phenotypic reversion from activation to quiescence.

Although the advanced understanding of the phenotype reversion of the activated HSCs has been made remarkable progress, treatment options for therapeutic strategy for the control of liver fibrogenesis are still severely limited (Yuan et al. 2019). It is urgent to establish the specific, effective, and safe anti-fibrotic therapeutic strategy, either by apoptosis, senescence, HSC phenotypic reversion, or inhibition of the HSCmediated angiogenesis. Recently, mounting evidence has demonstrated that HSCs are critical modulators of liver fibrogenesis via the reversal of their phenotype (Wei et al. 2019). In the near future, nanotechnology could be very promising in the innovative therapeutic approaches of liver fibrosis via targeting HSCs (Li et al. 2020, Tao et al. 2019). For example, targeted therapy reverses hepatic fibrosis via exosome mediated delivery system.

In conclusion, this study has offered significant insights regarding HSCs in the liver, providing prospects for emerging target therapies in patients with liver fibrosis.

\section{Abbreviations}

ALD, alcoholic liver disease; ECM, excessive extracellular matrix; HSCs, hepatic stellate cells; LRAT, lecithin retinol acetyl transferase; LSECs, liver sinusoidal endothelia cells; MMP, matrix metallo proteinase; NAFLD, non-alcoholic fatty liver disease; NASH, nonalcoholic steatohepatitis; NPCs, non-parenchymal cells; PH, partial hepatectomy; PPARs, peroxisome proliferator-activated receptors; RBP, retinol-binding protein; rER, rough endoplasmic reticulum; TGF- $\beta$, transforming growth factor- $\beta$; VEGF, vascular endothelial growth factor; $\alpha$-SMA, $\alpha$-smooth muscle actin

\section{Conflict of Interest}

There is no conflict of interest.

\section{Acknowledgements}

This study was supported by 2020 SF-067. 


\section{References}

ARAB JP, CABRERA D, SEHRAWAT TS, JALAN-SAKRIKAR N, VERMA VK, SIMONETTO D, CAO S, YAQOOB U, LEON J, FREIRE M, VARGAS JI, DE ASSUNCAO TM, KWON JH, GUO Y, KOSTALLARI E, CAI Q, KISSELEVA T, OH Y, ARRESE M, HUEBERT RC, SHAH VH: Hepatic stellate cell activation promotes alcohol-induced steatohepatitis through Igfbp3 and SerpinA12, J Hepatol 73: 149-160, 2020. https://doi:10.1016/j.jhep.2020.02.005

ARRIOLA BENITEZ PC, PESCE VIGLIETTI AI, GOMES MTR, OLIVEIRA SC, QUARLERI JF, GIAMBARTOLOMEI GH, DELPINO MV: Brucella abortus Infection Elicited Hepatic Stellate Cell-Mediated Fibrosis Through Inflammasome-Dependent IL-1beta Production, Front Immunol 10: 3036, 2019. https://doi:10.3389/fimmu.2019.03036

BANSAL MB: Hepatic stellate cells: fibrogenic, regenerative or both? Heterogeneity and context are key, Hepatol Int 10: 902-908, 2016. https://doi:10.1007/s12072-016-9758-x

CHEN H, GAN Q, YANG C, PENG X, QIN J, QIU S, JIANG Y, TU S, HE Y, LI S, YANG H, TAO L, PENG Y: Correction to: A novel role of glutathione S-transferase A3 in inhibiting hepatic stellate cell activation and rat hepatic fibrosis, J Transl Med 18: 182, 2020. https://doi:10.1186/s12967-020-02346-4

CHEN W, YAN X, YANG A, XU A, HUANG T, YOU H: miRNA-150-5p promotes hepatic stellate cell proliferation and sensitizes hepatocyte apoptosis during liver fibrosis, Epigenomics 12: 53-67, 2020. https://doi:10.2217/epi2019-0104

DAS D, FAYAZZADEH E, LI X, KOIRALA N, WADERA A, LANG M, ZERNIC M, PANICK C, NESBITT P, MCLENNAN G: Quiescent hepatic stellate cells induce toxicity and sensitivity to doxorubicin in cancer cells through a caspase-independent cell death pathway: Central role of apoptosis-inducing factor, J Cell Physiol 235: 6167-6182, 2020. https://doi:10.1002/jcp.29545

DEROSSI C, BAMBINO K, MORRISON J, SAKARIN I, VILLACORTA-MARTIN C, ZHANG C, ELLIS JL, FIEL MI, YBANEZ M, LEE YA, HUANG KL, YIN C, SAKAGUCHI TF, FRIEDMAN SL, VILLANUEVA A, CHU J: Mannose Phosphate Isomerase and Mannose Regulate Hepatic Stellate Cell Activation and Fibrosis in Zebrafish and Humans, Hepatology 70: 2107-2122, 2019. https://doi:10.1002/hep.30677

DOHERTY DG: Immunity, tolerance and autoimmunity in the liver: A comprehensive review, J Autoimmun 66: 60-75, 2016. https://doi:10.1016/j.jaut.2015.08.020

DONG L, PU Y, CHEN X, QI X, ZHANG L, XU L, LI W, MA Y, ZHOU S, ZHU J, LI Y, WANG X, SU C: hUCMSC-extracellular vesicles downregulated hepatic stellate cell activation and reduced liver injury in S. japonicum-infected mice, Stem Cell Res Ther 11:21, 2020. https://doi:10.1186/s13287-019-1539-8

EGGERT T, GRETEN TF: Tumor regulation of the tissue environment in the liver, Pharmacol Ther 173: 47-57, 2017. https://doi:10.1016/j.pharmthera.2017.02.005

ELPEK GO: Cellular and molecular mechanisms in the pathogenesis of liver fibrosis: An update, World J Gastroenterol 20: 7260-7276, 2014. https://doi:10.3748/wjg.v20.i23.7260

FORBES SJ, NEWSOME PN: Liver regeneration - mechanisms and models to clinical application, Nat Rev Gastroenterol Hepatol 13: 473-485, 2016. https://doi:10.1038/nrgastro.2016.97

FRIEDMAN SL: Hepatic stellate cells: protean, multifunctional, and enigmatic cells of the liver, Physiol Rev 88: 125-172, 2008a. https://doi:10.1152/physrev.00013.2007

FRIEDMAN SL: Mechanisms of hepatic fibrogenesis, Gastroenterology 134: 1655-1669, $2008 \mathrm{~b}$. https://doi:10.1053/j.gastro.2008.03.003

HELLERBRAND C: Hepatic stellate cells--the pericytes in the liver, Pflugers Arch 465: 775-778, 2013. https://doi:10.1007/s00424-012-1209-5

HOFFMANN C, DJERIR NEH, DANCKAERT A, FERNANDES J, ROUX P, CHARRUEAU C, LACHAGES AM, CHARLOTTE F, BROCHERIOU I, CLEMENT K, ARON-WISNEWSKY J, FOUFELLE F, RATZIU V, HAINQUE B, BONNEFONT-ROUSSELOT D, BIGEY P, ESCRIOU V: Hepatic stellate cell hypertrophy is associated with metabolic liver fibrosis, Sci Rep 10: 3850, 2020. https://doi:10.1038/s41598-020-60615-0 
HSIEH CC, HUNG CH, LU L, QIAN S: Hepatic immune tolerance induced by hepatic stellate cells, World J Gastroenterol 21: 11887-11892, 2015. https://doi:10.3748/wjg.v21.i42.11887

HUANG Y, DENG X, LIANG J: Modulation of hepatic stellate cells and reversibility of hepatic fibrosis, Exp Cell Res 352: 420-426, 2017. https://doi:10.1016/j.yexcr.2017.02.038

JUNG YK, YIM HJ: Reversal of liver cirrhosis: current evidence and expectations, Korean J Intern Med 32: 213-228, 2017. https://doi:10.3904/kjim.2016.268

KITANO M, BLOOMSTON PM: Hepatic Stellate Cells and microRNAs in Pathogenesis of Liver Fibrosis, J Clin Med 5, 2016. https://doi:10.3390/jcm5030038

KONG D, CHEN L, HUANG W, ZHANG Z, WANG L, ZHANG F, ZHENG S: Combined therapy with ligustrazine and paeonol mitigates hepatic fibrosis through destroying mitochondrial integrity of stellate cell, Am J Transl Res 12: 1255-1266, 2020.

KOYAMA Y, BRENNER DA: Liver inflammation and fibrosis, J Clin Invest 127: 55-64, 2017. https://doi:10.1172/JCI88881

KOYAMA Y, XU J, LIU X, BRENNER DA: New Developments on the Treatment of Liver Fibrosis, Dig Dis 34: 589-596, 2016. https://doi:10.1159/000445269

LEE YA, WALLACE MC, FRIEDMAN SL: Pathobiology of liver fibrosis: a translational success story, Gut 64: 830-841, 2015. https://doi:10.1136/gutjnl-2014-306842

LI F, HUANGYANG P, BURROWS M, GUO K, RISCAL R, GODFREY J, LEE KE, LIN N, LEE P, BLAIR IA, KEITH B, LI B, SIMON MC: FBP1 loss disrupts liver metabolism and promotes tumorigenesis through a hepatic stellate cell senescence secretome, Nat Cell Biol 22: 728-739, 2020. https://doi:10.1038/s41556-020$\underline{0511-2}$

LI Y, ZHANG Y, CHEN T, HUANG Y, ZHANG Y, GENG S, LI X: Role of aldosterone in the activation of primary mice hepatic stellate cell and liver fibrosis via NLRP3 inflammasome, J Gastroenterol Hepatol 35: 1069-1077, 2020. https://doi:10.1111/jgh.14961

LV F, LI N, KONG M, WU J, FAN Z, MIAO D, XU Y, YE Q, WANG Y: CDKN2a/p16 Antagonizes Hepatic Stellate Cell Activation and Liver Fibrosis by Modulating ROS Levels, Front Cell Dev Biol 8: 176, 2020. https://doi:10.3389/fcell.2020.00176

MARRONE G, SHAH VH, GRACIA-SANCHO J: Sinusoidal communication in liver fibrosis and regeneration, J Hepatol 65: 608-617, 2016. https://doi:10.1016/j.jhep.2016.04.018

MAZZA G, AL-AKKAD W, ROMBOUTS K: Engineering in vitro models of hepatofibrogenesis, Adv Drug Deliv Rev 121: 147-157, 2017. https://doi:10.1016/j.addr.2017.05.018

MIYAZOE Y, MIUMA S, MIYAAKI H, KANDA Y, NAKASHIKI S, SASAKI R, HARAGUCHI M, SHIBATA H, HONDA T, TAURA N, NAKAO K: Extracellular vesicles from senescent hepatic stellate cells promote cell viability of hepatoma cells through increasing EGF secretion from differentiated THP-1 cells, Biomed Rep 12: 163-170, 2020. https://doi:10.3892/br.2020.1279

MOON MY, KIM HJ, KIM MJ, UHM S, PARK JW, SUK KT, PARK JB, KIM DJ, KIM SE: Rap1 regulates hepatic stellate cell migration through the modulation of RhoA activity in response to TGFbeta1, Int J Mol Med 44: 491-502, 2019. https://doi:10.3892/ijmm.2019.4215

NAGASAKI A, SAKAMOTO S, CHEA C, ISHIDA E, FURUSHO H, FUJII M, TAKATA T, MIYAUCHI M: Odontogenic infection by Porphyromonas gingivalis exacerbates fibrosis in NASH via hepatic stellate cell activation, Sci Rep 10: 4134, 2020. https://doi:10.1038/s41598-020-60904-8

PREZIOSI ME, MONGA SP: Update on the Mechanisms of Liver Regeneration, Semin Liver Dis 37: 141-151, 2017. https://doi:10.1055/s-0037-1601351

SCHILDBERG FA, SHARPE AH, TURLEY SJ: Hepatic immune regulation by stromal cells, Curr Opin Immunol 32: 1-6, 2015. https://doi:10.1016/j.coi.2014.10.002

SCHUMACHER JD, GUO GL: Regulation of Hepatic Stellate Cells and Fibrogenesis by Fibroblast Growth Factors, Biomed Res Int 2016: 8323747, 2016. https://doi:10.1155/2016/8323747

SEKI E, BRENNER DA: Recent advancement of molecular mechanisms of liver fibrosis, J Hepatobiliary Pancreat Sci 22: 512-518, 2015. https://doi:10.1002/jhbp. 245 
SEKI E, SCHWABE RF: Hepatic inflammation and fibrosis: functional links and key pathways, Hepatology 61: 1066-1079, 2015. https://doi:10.1002/hep.27332

SEO W, JEONG WI: Hepatic non-parenchymal cells: Master regulators of alcoholic liver disease?, World J Gastroenterol 22: 1348-1356, 2016. https://doi:10.3748/wig.v22.i4.1348

SHANG L, HOSSEINI M, LIU X, KISSELEVA T, BRENNER DA: Human hepatic stellate cell isolation and characterization, J Gastroenterol 53: 6-17, 2018. https://doi:10.1007/s00535-017-1404-4

SHERMAN MH: Stellate Cells in Tissue Repair, Inflammation, and Cancer, Annu Rev Cell Dev Biol 34: 333-355, 2018. https://doi:10.1146/annurev-cellbio-100617-062855

TAO L, MA W, WU L, XU M, YANG Y, ZHANG W, SHA W, LI H, XU J, FENG R, XUE D, ZHANG J, DOOLEY S, SEKI E, LIU P, LIU C: Glial cell line-derived neurotrophic factor (GDNF) mediates hepatic stellate cell activation via ALK5/Smad signalling, Gut 68: 2214-2227, 2019. https://doi:10.1136/gutjnl-2018-317872

TAO L, WU L, ZHANG W, MA WT, YANG GY, ZHANG J, XUE DY, CHEN B, LIU C: Peroxisome proliferatoractivated receptor gamma inhibits hepatic stellate cell activation regulated by miR-942 in chronic hepatitis B liver fibrosis, Life Sci 253: 117572, 2020. https://doi:10.1016/j.1fs.2020.117572

THOMPSON AI, CONROY KP, HENDERSON NC: Hepatic stellate cells: central modulators of hepatic carcinogenesis, BMC Gastroenterol 15: 63, 2015. https://doi:10.1186/s12876-015-0291-5

TSUCHIDA T, FRIEDMAN SL: Mechanisms of hepatic stellate cell activation, Nat Rev Gastroenterol Hepatol 14: 397-411, 2017. https://doi:10.1038/nrgastro.2017.38

VAN GRUNSVEN LA: 3D in vitro models of liver fibrosis, Adv Drug Deliv Rev 121: 133-146, 2017. https://doi:10.1016/j.addr.2017.07.004

WANG L, WANG Y, QUAN J: Exosomes derived from natural killer cells inhibit hepatic stellate cell activation and liver fibrosis, Hum Cell 33: 582-589, 2020. https://doi:10.1007/s13577-020-00371-5

WANG Q, WEI S, ZHOU H, LI L, ZHOU S, SHI C, SHI Y, QIU J, LU L: MicroRNA-98 Inhibits Hepatic Stellate Cell Activation and Attenuates Liver Fibrosis by Regulating HLF Expression, Front Cell Dev Biol 8: 513, 2020. https://doi:10.3389/fcell.2020.00513

WANG ZM, XIA SW, ZHANG T, WANG ZY, YANG X, KAI J, CHENG XD, SHAO JJ, TAN SZ, CHEN AP, WANG SJ, ZHANG F, ZHANG ZL, ZHENG SZ: LncRNA-H19 induces hepatic stellate cell activation via upregulating alcohol dehydrogenase III-mediated retinoic acid signals, Int Immunopharmacol 84: 106470, 2020. https://doi:10.1016/j.intimp.2020.106470

WEI S, WANG Q, ZHOU H, QIU J, LI C, SHI C, ZHOU S, LIU R, LU L: miR-455-3p Alleviates Hepatic Stellate Cell Activation and Liver Fibrosis by Suppressing HSF1 Expression, Mol Ther Nucleic Acids 16: 758-769, 2019. https://doi:10.1016/j.omtn.2019.05.001

YANG L, HAN B, ZHANG M, WANG YH, TAO K, ZHU MX, HE K, ZHANG ZG, HOU S: Activation of BK Channels Prevents Hepatic Stellate Cell Activation and Liver Fibrosis Through the Suppression of TGFbeta1/SMAD3 and JAK/STAT3 Profibrotic Signaling Pathways, Front Pharmacol 11: 165, 2020. https://doi:10.3389/fphar.2020.00165

YANGUAS SC, COGLIATI B, WILLEBRORDS J, MAES M, COLLE I, VAN DEN BOSSCHE B, DE OLIVEIRA C, ANDRAUS W, ALVES VAF, LECLERCQ I, VINKEN M: Experimental models of liver fibrosis, Arch Toxicol 90: 1025-1048, 2016. https://doi:10.1007/s00204-015-1543-4

YIN C, EVASON KJ, ASAHINA K, STAINIER DY: Hepatic stellate cells in liver development, regeneration, and cancer, J Clin Invest 123: 1902-1910, 2013. https://doi:10.1172/JCI66369

YUAN B, CHEN Y, WU Z, ZHANG L, ZHUANG Y, ZHAO X, NIU H, CHENG JC, ZENG Z: Proteomic Profiling of Human Hepatic Stellate Cell Line LX2 Responses to Irradiation and TGF-beta1, J Proteome Res 18: 508-521, 2019. https://doi:10.1021/acs.jproteome.8b00814

ZHAI X, WANG W, DOU D, MA Y, GANG D, JIANG Z, SHI B, JIN B: A novel technique to prepare a single cell suspension of isolated quiescent human hepatic stellate cells, Sci Rep 9: 12757, 2019. https://doi:10.1038/s41598-019-49287-7

ZHANG CY, YUAN WG, HE P, LEI JH, WANG CX: Liver fibrosis and hepatic stellate cells: Etiology, pathological hallmarks and therapeutic targets, World J Gastroenterol 22: 10512-10522, 2016. https://doi:10.3748/wjg.v22.i48.10512 
ZHANG R, GAO X, ZUO J, HU B, YANG J, ZHAO J, CHEN J: STMN1 upregulation mediates hepatocellular carcinoma and hepatic stellate cell crosstalk to aggravate cancer by triggering the MET pathway, Cancer Sci 111: 406-417, 2020. https://doi:10.1111/cas.14262

ZHANG Z, WEN H, WENG J, FENG L, LIU H, HU X, ZENG F: Silencing of EPCAM suppresses hepatic fibrosis and hepatic stellate cell proliferation in mice with alcoholic hepatitis via the PI3K/Akt/mTOR signaling pathway, Cell Cycle 18: 2239-2254, 2019. https://doi:10.1080/15384101.2019.1642067

ZHOU WC, ZHANG QB, QIAO L: Pathogenesis of liver cirrhosis, World J Gastroenterol 20: 7312-7324, 2014. https://doi:10.3748/wjg.v20.i23.7312

ZOU GL, ZUO S, LU S, HU RH, LU YY, YANG J, DENG KS, WU YT, MU M, ZHU JJ, ZENG JZ, ZHANG BF, WU X, ZHAO XK, LI HY: Bone morphogenetic protein-7 represses hepatic stellate cell activation and liver fibrosis via regulation of TGF-beta/Smad signaling pathway, World J Gastroenterol 25: 4222-4234, 2019. https://doi:10.3748/wjg.v25.i30.4222

ZOUBEK ME, TRAUTWEIN C, STRNAD P: Reversal of liver fibrosis: From fiction to reality, Best Pract Res Clin Gastroenterol 31: 129-141, 2017. https://doi:10.1016/j.bpg.2017.04.005 